\title{
Effect of Sub Lethal Concentration of Malathion on Metabolic Profiles and Histological Studies in Heart Tissue of Channa Punctatus
}

\author{
${ }^{1}$ Magar R.S., ${ }^{2}$ Dube K. V. \\ ${ }^{1,2}$ P.G. Department of Zoology, Yeshwant Mahavidyalaya Nanded-431603.
}

\begin{abstract}
Pesticides have an innate capacity to cause damage to biological system. Considering above fact the present study deals with the effect of the insecticide malathion on histological and biochemical study on cardiac muscle tissue in Channa punctatus. In present study effect of sub lethal concentration (0.8 ppm) of malathion on protein, lipid and glycogen content and histopathological changes in heart tissue of fresh water fish Channa punctatus during 96 hours was studied. Structural variations like congestion, atrophy were observed in cardiac muscle of Channa puncctatus during 96 hours sub lethal treatment of malathion. Total protein, lipid and glycogen showed decrement in cardiac muscle of Channa punctatus
\end{abstract}

Keywords: Malathion, sub lethal, cardiac muscle, Channa punctatus.

\section{Introduction}

For centuries pesticides have been used in agriculture to enhance food production by eradicating unwanted insects and controlling disease vectors. These pesticides ultimately reach the aquatic systems through different pathways affecting various aquatic organisms. Beside direct deposition or drift, these compound may reach aquatic habitats via run of, depending upon the precipitation, soil condition and slope of catchment area (Santhakumar et al. 1999). Among these pesticides, organophosphorous compounds are commonly used insecticides. Malathion is commonly used organophosphorous pesticide. While most of the malathion will stay in the areas where it is applied, some can move to areas away from where it was applied by rain, fog and wind. Once malathion is introduced into the environment, it may cause serious intimidation to aquatic organisms and is notorious to cause severe metabolic disturbances in non target species like fish and fresh water mussels (USEPA, 2005).

Channa punctatus is common fresh water fish abundantly present in local river Godavari Dist. Nanded. It is one of the major source of food of poor population in local area. Cardiac muscle is the major tissue component of fish and responsible for continuous supply of blood to whole body of fish. Scanty reports were available regarding biochemical and histological manifestation induced by pesticide on cardiac tissue of fish. Since, malathion is being extensively used in agriculture, there is scope to transfer to non-target organisms due to bioaccumulation and biomagnifications in existed environment. Hence the toxic impact of malathion on cardiac tissue of fresh water fish Channa punctatus was attempted.

\section{Material And Methods}

For present study, commercial grade malathion $(50 \% \mathrm{EC}$, manufactured by Coromandal fertilizer limited, Coromandal house, pesticide division, Ranipet, Vellore (TN), India) was procured from the local market. Healthy specimens of Channa punctatus were collected from local river Godavari Dist. Nanded. Their avarage length and wet weight $( \pm \mathrm{SD})$ were recorded as $23 \pm 2 \mathrm{~cm}$ and $80 \pm 4$ gms respectively. Fishes were treated with $0.1 \% \mathrm{KmNo}_{4}$ solution for 2 min. to avoid any dermal infection. The fish stock was then maintained in 100 liter glass aquaria for 14 days to acclimatize under laboratory condition. The fishes were fed with pieces of live earth warm on alternate days. A stock solution was prepared in acetone and mixed in water to obtain required dilutions. The $\mathrm{LC}_{50}$ value for 96 hours of malathion was determined by procedure of Finney (1971). The $\mathrm{LC}_{50}$ of malathion for 96 hours for Channa punctaus was $4 \mathrm{mg} / \mathrm{liter}$. Fishes were exposed to sub lethal concentration $(0.8 \mathrm{ppm})$ of malathion, simultaneously control group was also maintained. For histological investigation muscle tissue were fixed in $10 \%$ formalin, dehydrated, embedded in paraffin wax and sectioned at $6 \mu \mathrm{m}$ then stend with haematoxylin and eosin and examined microscopically and photographed.

For biochemical studies heart muscle of control and experimental groups of fishes were sacrificed after 24, 48, 72 and 96 hours. Total protein content was determined according to the method of Lowry et al.(1951). The total lipid content was estimated by the method of Bligh and Dyer (1959). Glycogen content was estimated by Anthrone method (Hedge and Hofrciter, 1962). 


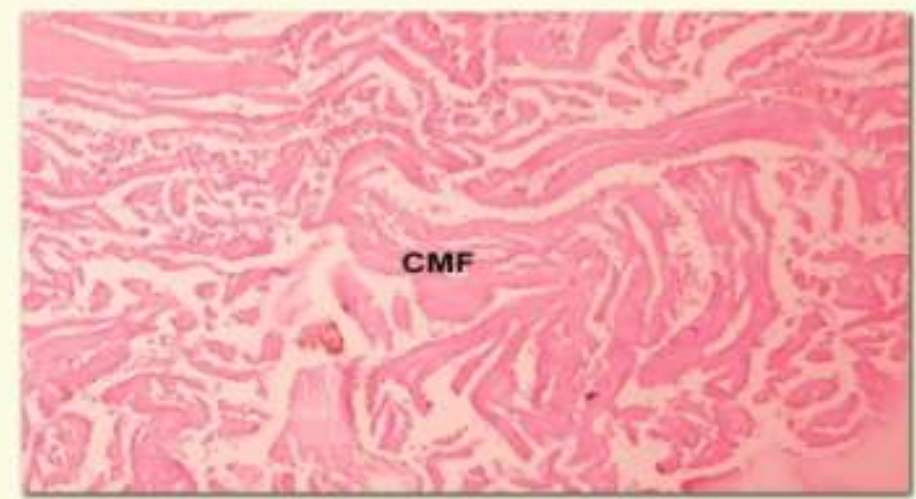

Plate - 1 Photomicrograph of V.S. of Heart of Control

fish Channa punctatus

(CMF-Cardiac Muscle Fibers)

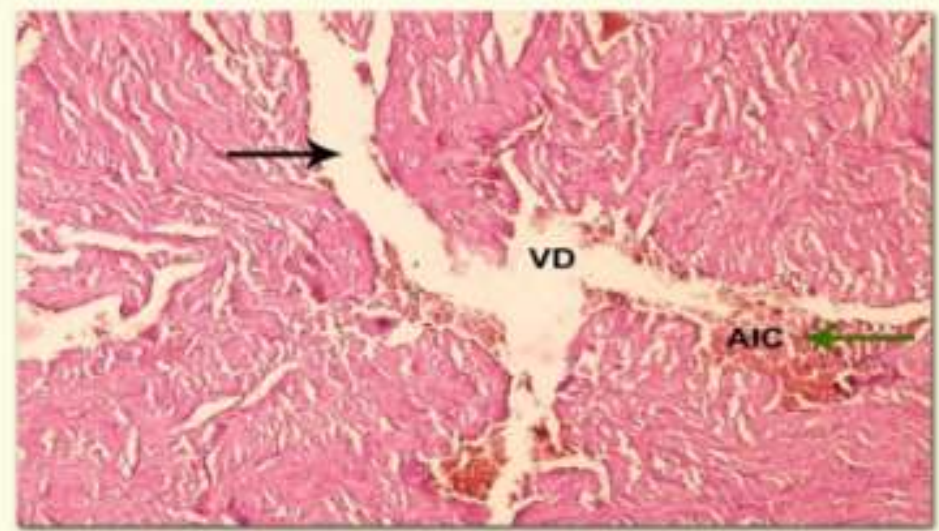

Plate - 2 Photomicrograph of V.S. of Heart of Channa punctatus after 96 hours exposure to Malathion (VD - Vacuolar Degeneration; AIC - Aggrigated Inflammatory

Table-1 Levels of total protein, Lipid and Glycogen content in cardiac muscle tissue of Channa punctatus after exposure to sub lethal concentration of malathion.

\begin{tabular}{|l|l|l|l|}
\hline Time in hours & Total protein & Total lipid & Glycogen \\
\hline Control (00 hours) & $76.03 \pm 1.01$ & $50.10 \pm 1.34$ & $14.15 \pm 1.12$ \\
\hline 24 hours & $69.25 \pm 1.54^{*}$ & $48.21 \pm 1.33$ & $13.99 \pm 1.52^{* * *}$ \\
\hline $\mathbf{4 8}$ hours & $77.50 \pm 1.18^{*}$ & $45.93 \pm 2.12^{* * * *}$ & $12.24 \pm 1.03$ \\
\hline $\mathbf{7 2}$ hours & $74.03 \pm 1.41$ & $43.28 \pm 1.92^{* * * *}$ & $10.55 \pm 0.17$ \\
\hline 96 hour & $64.20 \pm 1.50^{*}$ & $40.93 \pm 1.49^{* * * *}$ & $8.56 \pm 0.85^{*}$ \\
\hline
\end{tabular}

[values are expressed as $\mathrm{mg} / \mathrm{gm}$ wet wt of tissue. Values are mean $\pm \mathrm{SD}$ of six replicates * $\mathrm{p}<0.05, * * \mathrm{P}<0.01, * * * \mathrm{p}>0.01$, significant when student's test was applied between control and experimental groups.]

\section{Result}

In the present study it was observed that when the fresh water fish Channa punctatus exposed to sub lethal concentration of malathion showed decreased in the level of protein in cardiac muscle of treated group during 96 hours (64.20) compared with control (76.03) while total lipid content decreased (40.93) during 96 hours compared with control (50.10). Glycogen content in cardiac muscle also decreased (8.56) during 96 hours compared with control (14.15)

(Table -1). 
Plate 1- Showed V.S. of normal structure of heart of Channa punctatus. In Plate 2- treated cardiac muscle were observed. In treated section of cardiac muscle showed congesation and atrophy. Cardiac muscle fibers started to separate from each other and vacuolar degeneration of muscle fiber was observed. In some area cardiac muscle showed haemorrage and haemolysis along with aggregation of inflammatory cells were observed in treated myocardial fibers.

\section{Discussion}

In present study, the fish Channa punctatus exposed to malathion showed significant alteration in histological and biochemical parameters of cardiac tissue. The cardiac tissue accupied significant postion in circulation of fish. Since the cardiac muscles selected for the present study is some amount of pesticide might have focused its entry into the tissue through the circulatory system thus causing structural and biochemical changes to cell system.

Scanty research work has been done on changes associated with cardiac muscle to sub lethal exposure of pesticide. In present investigation alterations in structure of cardiac muscle in fish Channa punctatus under sub-lethal treatment of malathion has been observed. Cardiac muscle showed degeneration and atrophy. Borges et al., (2003) reported acute effect of heavy metal vanadate oligomers on cardiac muscle of Toadfish (Halobatrachus didactylus). They concluded that heavy metal vandate oligomers induced hypertrophy of ventricle due to a decrease in the percentage of myocardium. Moreover vacuolar degeneration was seen in myocardial muscle. After passing through the blood vascular system the pesticide malathion targeted cardiac muscle fibers, causing extensive damage of myocardium.

The myocardial fibers degeneration observed in present study could be attributed to the excessive calcium accumulation as previously reported by Lennard and Huddart (1992). Nagarjuna and Doss (2009) studied protein profile and histopathology in heart tissues of rat during cpermethrin toxicosis. They noted under sub lethal concentration of cypermethrin $(41 \mathrm{mg} / \mathrm{kg}$ ) cardic muscle of rat showed congestion and slight inflataration. Das and Mukherjee (2000) studied histopathology of organ like liver, kidney, gill, skin, muscle, heart and brain of Labeo rohita exposed to 1/10 and 1/5 sub-lethal doses of hexachlorocyclohexane during 45 days. They observed changes in pericardium and myocardium of fish Labeo rohita under sub-lethal treatment of $\mathrm{HCH}$. They concluded under $\mathrm{HCH}$ treatment fragmentation of myofibrils and cellular infiltration of cardiac muscle in fish. Mohammed (2008) studied bioaccumulation of selected metals and histopathological alterations in tissues of Oreochromis niloticus and Lates niloticus from lake Nasser, Egypt. They found that metals were accumulated in different tissues like liver, gill, kidney, muscle and cardiac muscle of both fishes by various levels, where the non-edible parts accumulated more metal than the edible muscles. He observed degeneration and atrophy in cardiac muscle fiber and degeneration in muscle bundles of both fishes as a result of accumulated metals ( $\mathrm{Fe}, \mathrm{Zn}, \mathrm{Pb}, \mathrm{Cd}$ and $\mathrm{Co}$ ). H. Soufy et al., (2007) studied biochemical and pathological investigations on Monosex tilapia following chronic exposure to $1 / 10 \mathrm{LC}_{50}$ of carbofurna pesticide. They revealed various degrees of pathological lesions in different organs like gill, heptopancreas, spleen, kidney, brain, intestine, skin and heart of Monosex tilapia under carbofuran treatment. They showed significant changes in heart muscle like congestion in between muscle fibers and cell infiltaration during exposure carbofuran in Monosex tilapia. Since pesticide residues are more accumulated in muscle and fat tissues of fish, it can reach the human body through food causing health hazards.

Protein is most characteristic organic compound found in the living cell while the protoplasm of the cell is composed of protein. They play vital role in the process of interaction of cellular medium.

In experimentation, after 96 hours the decline in protein content was observed. This fall from the next onward day be attributed to the constantly increasing contact of the pesticide with the biosystem which ultimately resulted in protein breakdown. Kabeer (1979) showed increase in protein content in fish, Tilapia mossambica treated with methyl parathion and malathion.

Even though most of the workers found that, there was reduction in protein contents in various tissues of the animal under different stress conditions. The decrease in protein content may be due to reduced protein synthesis and increased proteolysis. Joseph, (1987) observed the effect of copper on biochemical composition of Cyprinus carpio and found that total protein content of the brain, liver and muscle were declined.

Ramalingam and Ramalingam (1982) stated that proteins expected to involve in the compensatory mechanism of stressed organisms similar observation were made by Jagdeesen et al. (1999). Chandravathy and Reddy (1994) suggested that decline in the muscle protein content might be due to reduced protein synthesis, increased proteolysis and also due to utilization for metabolic process under lead toxicity. Rao et al. (1987) and Baskaren et al. (1989) reported reduction in protein content could be due to its utilization to mitigate the energy demand when the fish is under stress.

Decrease in protein content at sub lethal exposure of malthion to fresh water fish, Channa punctatus suggest the possible utilization of protein for various metabolic purposes and enhanced proteolysis to meet the high energy demand under pesticidal stress. 
During present investigation a significant decrease in lipid content after exposure to malathion was observed in muscle of Channa punctatus. Reduction in level of lipid content suggests that organic reserves seem to have utilized during four days. This situation provides important information regarding adaptive ability of Channa punctatus during pesticidal stress P. Amudha et al., (1993) suggested that lipid content of fish reduced with increasing concentration of pollution. They showed that reduction in lipid content might be due to utilization of lipid as a source of energy during stressful condition. Gupta (1987) has also reported that lipid content decreased in various tissues of Channa punctatus with increasing concentration of vegetable oil factory efficient Choudhary et al. (1981) studied the effect of malathion on the behavior and body composition of the Heteropneustes fossilis and found that the water and lipid contents of the whole body and ovary decreased as compared to control. Lomte and Sabiha Alam (1984) showed effect of malathion on the biochemical components of the proso branch, Belamia bengalnsis and reported that the decrease in glycogen, protein and lipid under pesticidal stress. Decrease in tissue lipid and proteins might be partly due to their utilization in cell repair and tissue organization with the formation of lipoproteins, which are important cellular constituents of cell membranes, and cell organelles present in the cytoplasm (Harper, 1983). Nagabushanam et al. (1972) showed decline in lipid content in the hepatopancreas of the fresh water prawn Macroranchium kristensis in response to pesticide.

The decreased glycogen content in cardiac muscle is attributed due to inhibiton of hormone and enzymes when the fish is under the influence of toxicant. During this time the conversion of carbohydrate into amino acid may be possible. Hence the decreasing trend in glycogen contents was noticed. Similar observations were made by (Gaiton et al. 1965; Stamp and Lesker, 1967; Edwards, 1973; Murthy, 1983; Anita Susan et al. 1999; Tilak 2002).

In conclusion it can be stated that sub lethal of malathion lead to alteration in structure of cardiac muscle tissue which leads into decrease in biochemical content like protein, lipid and glycogen. Fish with damaged heart showed significant effect regarding circulation in fish which disturb normal physiology of fish. This indicates that one should take necessary precaution in application of pesticide to protect life of fish.

\section{Acknowledgement}

Authors are thankful to the Principal, Dr. N.V. Kalyankar, Yeshwant Mahavidyalaya Nanded for providing laboratory facilities during this study.

\section{References}

[1] Amudha, P. and Mahalingam (1993) : Effect of diary effluents on the body composition of Cyprinus carpio (Cyprinidae). J. Ecotoxicol. Env. Moni. 9(1):3-8.

[2] Anita Susan, T.K. Veeraiah and K.S. Tilak (1999) : Biochemical changes in tissues of fish Catla catla is exoposed to fenvalerate TM a synthetic pyrethroid J. Ecobiol. 11(2): 109-116.

[3] Das B.K. and Mukherjee S.C (2000) : A histopathological study of carp (Labeo rohita) exposed to hexachlorocyclohexane. Veterinarsky. Arhiv. 70(4): 169-180.

[4] Baskaran, S., Palanichamy, P.S., Balasubramani, M.P. (1989) : Effect of pesticides on protein metabolism in the Mystus vittatus. J. Eco. Biol. 1(2) : 90-97.

[5] Bligh, E.G. and Dyer, W.J. (1959) : Can J. Biochem \& Physiol, 37-911.

[6] Chandravarthy, V.M. and Reddy, S.L.N. (1994) : In : vivo recovery of protein metabolism in gill and brain of fresh water fish, Anabus scadons after exposure to lead nitrte. J. Env. Biol. $15: 75-82$.

[7] Choudhary, B.P., P.K. Pandey and N.K. Dubey (1981) : Effect of malathion on the behavior and body composition of Heteropreustes fossilis. J. Env. Biol. 2(1) : 21-36.

[8] Edwards, C.A. (1973) : Environmental pollution by pesticides. Plenum Press. London New York.

[9] Fatima A.S. Mohammed (2008) : Bioaacumulation of selected metals and histopathological alterations in tissues of Orecochromis niloticus and Lates niloticus from lake Nasser, Egypt. Global.verterinia. 2(4) : 205-218.

[10] Finney, D. J. (1971) : 'Probit analysis' Third edition, Cambridge University, Press.

[11] G.Borges, P.Mendonca, N. Joaquim, J. Caucelo, M. Aureliano (2003) : Acute effects of vandate oligomers on heart, kidney and liver histology in the lusitanian Toadfish (Halobratrachus didactylus). Arch. Environ. Contom. Toxicol. 45 : 415-422.

[12] Gaiton, M.K., D.R. Dahl , K.A.L. Ellioth, (1965) : Entry of glucose carbonin to aminoacids of rat brain and liver in vivo after injection of uniformly C 14 labeled glucose. Biochem. Jr. 94 : 345-352.

[13] Gupta, S. (1987) : Effect of vegetable oil factory effluent on lipid content in liver of Channa punctatus (Bloch) in vitro incorporation of radio labeled substances J. Env. Biol. 8(4) : 353-357.

[14] H. Soufy, M.K. Soliman, E.M. El-Manakhly, A.Y. Gaafar (2007) : Some biochemical and pathological investigations on Monosex tilapia following chronic exposure to carbofuran pesticide. Global. Veterinaria. 1(1): 45-52.

[15] Harper, A.H. (1983) : Review of Biochemistry $20^{\text {th }}$ ed. Lange medical publications co, California, 1012.

[16] Hedge, J.E. and Hofreiter, B.T. (1962) : In : Carbohydrate chemistry 17 (Eds Whistler, R.L. and Be Miller, J.N.). Acadamic. Press. New York.

[17] Jagadeessan, G. and Mathivanan, A (1999) : Organic constituent's changes induced by three different sub lethal concentrations of mercury and recovery in the liver tissue of Labeo rohita fingerlings. Poll. Res. 18(2) : 177-181.

[18] Joseph (1987) : Chronic toxicity of copper on the biochemical composition of some tissues of the scale carp, Cyprinus carpio (Commemis), Proc. Nat. Conc. Env. Impact on Biosystem, 263-267.

[19] Kabeer, A.S.I. (1979) : Studies on some aspects of protein metabolism and associated enzyme system in the fresh water teleost, Tilapia mossambica subjected to malathion exposure, Ph.D. Thesis, Submitted to S.V. University, Tirupati, India. 
[20] Lennard, R. and H. Haddart (1992) : The effect of hypoxic stress on the fine structure of the flounder heart (Platichthys flesus) Comp. Biochem. and physiol. 101: 723-732.

[21] Lomte, V.S. and Sabiha Alam (1984) : Changes in the biochemical components of prosobranch, Belmia bengalensis on exposure to malathion, Proc. Att. Indian. Ymp. 69-72.

[22] Lowry, O.H., Rosenbrough, A.J., Farr, A.L., Randall, R.J. (1951) : Protein estimation with folin phenol reagent. J. Biol. Chem. 193 : 265-275.

[23] Santhakumar M., , Balaji M., Ramuda K. (1999): Effect of sub lethal concentrations of monocrotophos on erythropoietic activity and certain hematological parameters of fish Anabas testudineus (Bloch). Bull. Environ. Contom. Toxicol .63: 379-384.

[24] Nagarjuna, A., P. Jacob Doss (2009) : Protein metabolic profile and histopathological studies in heart of rats during cypermethrin toxicosis. Toxicol. Int. 16(2) : 91-95.

[25] Naghbhushan, R., J.Deshpande, R. Sarojini (1972) : Effect of some pesticides on the biochemical constituents of fresh water prawn Macrobranchium Kistheis. Proc.Nat. Symb. Ecotoxi, 73-84.

[26] Ramalingam, K. and Ramalingam, K. (1982) : Effect of sub lethal levels of DDT malathion and mercury on tissue proteins of Sarotherodon mossambicus Proc. Indian Acad. Sci. 6 : 501-504.

[27] Rao, S.K., Murthy, K.S., Reddy, B.K., Swani, K.S., Chetty, C.S.R. (1987) : Effect of benthiocarb on protein metabolism of fresh water teleost fish, Labeo rohita (Ham). Proc. Acad. Env. Biol. 7 : 143-148.

[28] Shrinivas Murthy, K. (1983) : Modulation of Carbohydrate and associated metabolism in the selected tissues of fresh water mussel (Lamellidens marginalis) during induced methyl parathion stress Ph.D., Thesis S.V. University, Tirupathi, A.P. India.

[29] Stamp, W.D. and P.A. Lesker, (1967) : Tetrazolium test for dehydrogenases. J. Sci.Ind. Res. 14-206.

[30] USEPA (2005) : United states environmental protection agency. 